\title{
A comparison of the effects of low- and conventional-dose thiazide diuretic on insulin action in hypertensive patients with NIDDM
}

\author{
R. Harper ${ }^{1}$, C.N. Ennis ${ }^{1}$, A.P.Heaney ${ }^{1}$, B. Sheridan ${ }^{2}$, M. Gormley ${ }^{3}$, A. B. Atkinson ${ }^{1}$, G. D. Johnston ${ }^{4}$, P. M. Bell ${ }^{1}$ \\ ${ }^{1}$ Sir George E. Clark Metabolic Unit, Royal Victoria Hospital, Belfast, UK \\ ${ }^{2}$ Regional Endocrine Laboratory, Royal Victoria Hospital, Belfast, UK \\ ${ }^{3}$ Mater Infirmorum Hospital, Belfast, UK \\ ${ }^{4}$ Department of Therapeutics and Pharmacology, The Queen's University of Belfast, Belfast, UK
}

Summary In conventional doses, thiazide diuretics impair glucose tolerance and decrease insulin sensitivity, making them an unpopular choice for treating diabetic patients with hypertension. However, use of lowdose thiazide diuretics may avoid the adverse metabolic effects seen with conventional doses. In a double-blind, randomised crossover study we assessed peripheral and hepatic insulin action in 13 hypertensive non-insulin-dependent diabetic patients after a 6-week placebo run-in and following two 12-week treatment periods with either low $(1.25 \mathrm{mg})$ or conventional $(5.0 \mathrm{mg})$ dose bendrofluazide. There were no differences between doses in their effects on systolic and diastolic blood pressure. Bendrofluazide $1.25 \mathrm{mg}$ had significantly less effect on serum potassium, uric acid, fasting glucose and $\mathrm{HbA}_{1 \mathrm{c}}$ concentrations than the $5.00 \mathrm{mg}$ dose. Exogenous glucose infusion rates required to maintain euglycaemia were significantly different between doses $(p<0.05)$ with conventional-dose bendrofluazide worsening peripheral insulin resistance compared to baseline $(23.8 \pm 2.9$ vs $\left.27.3 \pm 3.5 \mu \mathrm{mol} \cdot \mathrm{kg}^{-1} \cdot \mathrm{min}^{-1}, p<0.05\right)$ and low-dose bendrofluazide producing no change compared to baseline $\left(26.8 \pm 3.6\right.$ vs $27.3 \pm 3.5 \mu \mathrm{mol} \cdot \mathrm{kg}^{-1} \cdot \mathrm{min}^{-1}$, $p=$ NS). Postabsorptive endogenous glucose production was higher on treatment with bendrofluazide $5.0 \mathrm{mg}$ compared to $1.25 \mathrm{mg} \quad(11.7 \pm 0.5$ vs $\left.10.2 \pm 0.3 \mu \mathrm{mol} \cdot \mathrm{kg}^{-1} \cdot \mathrm{min}^{-1}, p<0.05\right)$ and suppressed to a lesser extent following insulin $(4.0 \pm 0.7$ vs $\left.2.0 \pm 0.4 \mu \mathrm{mol} \cdot \mathrm{kg}^{-1} \cdot \mathrm{min}^{-1}, \quad p<0.05\right)$. Treatment with bendrofluazide $5.0 \mathrm{mg}$ increased postabsorptive endogenous glucose production compared to baseline $\left(11.7 \pm 0.5\right.$ vs $10.6 \pm 0.4 \mu \mathrm{mol} \cdot \mathrm{kg}^{-1} \cdot \mathrm{min}^{-1}$, $p<0.05)$ whereas bendrofluazide $1.25 \mathrm{mg}$ did not (10.2 \pm 0.3 vs $\left.10.6 \pm 0.4 \mu \mathrm{mol} \cdot \mathrm{kg}^{-1} \cdot \mathrm{min}^{-1}, p=\mathrm{NS}\right)$. At a dose of $1.25 \mathrm{mg}$ bendrofluazide is as effective as conventional doses but has less adverse metabolic effects. In contrast to conventional doses which worsen both hepatic and peripheral insulin resistance, lowdose bendrofluazide has no effect on insulin action in non-insulin-dependent diabetic subjects. [Diabetologia (1995) 38: 853-859]

Key words Insulin resistance, hypertension, non-insulin-dependent diabetes mellitus, thiazide diuretic.
Arterial hypertension is well-established as an important risk factor for cardiovascular morbidity and mortality in patients with diabetes mellitus and treatment

Received: 6 September 1994 and in revised form: 29 December 1994

Corresponding author: Dr. P.M. Bell, Sir George E Clark Metabolic Unit, Royal Victoria Hospital, Belfast BT12 6BA, UK Abbreviations: EGP, Endogenous glucose production; $\mathrm{R}_{\mathrm{a}}$, rate of glucose appearance; $\mathbf{R}_{\mathrm{d}}$, rate of glucose disappearance; NIDDM, non-insulin-dependent diabetes mellitus. of hypertension is strongly recommended $[1,2]$. Since their introduction into clinical practice in 1957 [3], thiazide diuretics have remained a popular treatment for arterial hypertension, providing an effective, well-tolerated, once-daily treatment. They have been used in many of the large prospective clinical trials in mild hypertension, producing a consistent benefit, particularly in terms of reducing the excess risk of stroke [4-6].

However, thiazide diuretics have become an unpopular choice for the treatment of hypertension in diabetic subjects because they are associated with a 
number of potentially deleterious metabolic effects $[7,8]$, which may to some extent offset the benefit gained by blood pressure reduction [9]. These include hypokalaemia, hyperuricaemia, short-term hyperlipidaemia, impaired glucose tolerance and effects on insulin action. Adverse metabolic effects in a group with an already greatly-increased risk of vascular disease are clearly highly undesirable.

However, many of these adverse metabolic effects are dose-dependent and can be minimised by using lower doses [10-14]. The effectiveness of lowdose thiazide diuretics in the absence of adverse metabolic effects has been emphasised recently for bendrofluazide [10], cyclopenthiazide [11] and hydrochlorothiazide [12] in non-diabetic patients and for cyclopenthiazide [13] and hydrochlorothiazide [14] in diabetic hypertensive subjects. A recent study in non-diabetic hypertensive subjects showed that hydrochlorothiazide at conventional dosage appears to decrease insulin-mediated glucose disposal indicating an increase in peripheral insulin resistance [15]. We have shown recently that low-dose thiazide diuretic (bendrofluazide $1.25 \mathrm{mg}$ ) is an effective antihypertensive in non-diabetic subjects and does not have any adverse effects on peripheral insulin action [16].

The effects of antihypertensive medication on insulin action are of prime clinical relevance in patients with diabetes in whom metabolic derangement and both hepatic and peripheral insulin resistance are well-established and characteristic features [17]. At present, little information is available regarding the effects of thiazide diuretics on insulin action in diabetic subjects. In the present study we have examined the effects of $1.25 \mathrm{mg}$ and $5.0 \mathrm{mg}$ of bendrofluazide on insulin action in patients with mild hypertension and non-insulin-dependent diabetes (NIDDM) in a double-blind randomised crossover study. We have used the glucose clamp technique in conjunction with isotope dilution methodology to provide a detailed analysis of both peripheral and hepatic insulin action.

\section{Subjects and methods}

Subjects. Patients aged under 65 years with hypertension (either newly diagnosed or on treatment with a single agent) and NIDDM established on treatment with diet or oral hypoglycaemic agents with fasting plasma glucose in the range 5$11 \mathrm{mmol} \cdot 1^{-1}$ were recruited from the Royal Victoria Hospital and Mater Infirmorum Hospital Diabetes Clinics in Belfast. Patients were excluded from the study if they exceeded $125 \%$ of ideal body weight (Metropolitan Life Insurance tables, 1955), had significant cardiac, hepatic or renal disease, a history of gout, or were being treated with non-steroidal anti-inflammatory agents or corticosteroids. Patients with secondary hypertension were excluded. Patients with diastolic blood pressure outside the range $95-110 \mathrm{~mm} \mathrm{Hg}$ after a placebo runin period of 6 weeks were not studied.
All patients gave written informed consent to the protocol which was approved by the Ethical Committee of The Queen's University of Belfast.

Study design. A randomised double-blind crossover design was employed. All antihypertensive agents were discontinued and placebo substituted for 6 weeks. At the end of this period, during which patients were seen at 2-weekly intervals, patients with a diastolic blood pressure greater than $95 \mathrm{~mm} \mathrm{Hg}$ were eligible to continue. Patients were randomised to receive either $1.25 \mathrm{mg}$ or $5.0 \mathrm{mg}$ bendrofluazide as a single daily dose for a 12 -week period. The randomisation was designed to ensure that the numbers receiving each treatment during the first treatment phase were equal. During this period, patients were reviewed at 4-weekly intervals. When 12 weeks had elapsed, patients were once again started on placebo for a further 6 weeks, after which they received the alternative dose of bendrofluazide for 12 weeks. Patients were assessed at 4 and 6 weeks into this second placebo period and at 4-week intervals during the second treatment period of 12 weeks. All medication was supplied by Boots Pharmaceuticals, Nottingham, UK. Placebo and active tablets were identical in taste and appearance. Patients were asked to bring the study medication with them at each visit to check on compliance. Treatment with oral hypoglycaemic agents continued unchanged throughout the study.

Methods of assessment. Throughout the trial patients were seen by the same investigator. At each assessment patients attended fasting and blood pressure readings were taken in the same arm at the same time of day. After resting supine for $10 \mathrm{~min}$, blood pressure was measured with the arm supported at heart level using a Hawksley random zero sphygmomanometer. Arterial pressure was measured to the nearest $2 \mathrm{~mm} \mathrm{Hg}$. Disappearance of the Korotkoff sounds (Phase V) was taken as a measure of diastolic blood pressure. The mean of three readings was used. At each visit heart rate and weight were measured and, avoiding forearm exercise, venous blood was drawn for plasma glucose, serum urea, urate and electrolytes, glycated haemoglobin, haemoglobin and lipid profile.

Insulin action was assessed at the end of the run-in period and at the end of the two active treatment periods using the euglycaemic glucose clamp technique $[18,19]$. Patients were admitted to the Metabolic Unit at 07.45 hours on the morning of the study after a 12 -h overnight fast. No medication was given on the morning of the glucose clamp. An antecubital vein was cannulated (18-gauge cannula, Venflon Viggo, Helsingborg, Sweden) and used for all infusions. A dorsal hand vein in the contralateral arm was cannulated (21-gauge, Venflon Viggo) and the hand placed in a thermoregulated plexiglass box (Northern Ireland Technology Centre, Automation Division, Queen's University of Belfast, Belfast, UK) maintained at $55^{\circ} \mathrm{C}$ to allow intermittent sampling of arterialised venous blood.

A primed continuous infusion of HPLC purified [6${ }^{3} \mathrm{H}$ ]glucose (New England Nuclear Research Products Division, Dupont Ltd., Stevenage, UK) (NET 100C) was given during a 2-h equilibration period ( -120 to $0 \mathrm{~min})$, after which a 2$\mathrm{h}$ continuous infusion of insulin (Humulin S, Eli Lilly and Company Limited, Basingstoke, UK) was commenced at a rate of $2 \mathrm{mU} \cdot \mathrm{kg}^{-1} \cdot \mathrm{min}^{-1}$. The initial tracer prime was adjusted based on the fasting blood glucose as previously described [20]. Plasma glucose was maintained at the fasting level on the initial and subsequent glucose clamps by an exogenous glucose infusion (20\%). Exogenous glucose was pre-labelled with $\left[6-{ }^{3} \mathrm{H}\right]$ glucose to match the predicted basal plasma glucose specific activity as previously described [21] with the modification 
that the primed continuous tracer infusion was reduced to $50 \%$ of basal rate after $20 \mathrm{~min}$ and to $25 \%$ of basal rate after 40 min of insulin infusion (in order to maintain tracer steady state) and was maintained at this reduced rate throughout the remainder of the hyperinsulinaemic period.

Serum non-esterified fatty acids (NEFA), $\beta$-hydroxybutyrate and glycerol levels were measured during hyperinsulinaemia to assess the impact of bendrofluazide treatment on insulin's antilipolytic effect.

Analytical techniques. Arterialized venous blood was used for all analyses. Plasma for glucose specific activity was deproteinized using $\mathrm{Ba}(\mathrm{OH})_{2}$ and $\mathrm{ZnSO}_{4}$ by the method of Somogyi [22] and after centrifugation the supernatant was passed sequentially through anion (AG1-X8, BioRad Laboratories, Watford, UK) and cation (AG50W-X8, BioRad) exchange columns to remove charged molecules. Samples were counted in a liquid scintillation spectrometer (Tri-Carb 2000 CA, Canberra Packard, Pangbourne, UK). Aliquots of tracer infusate and labelled exogenous glucose infusion were spiked into nonradioactive plasma and were processed in parallel with plasma samples to allow calculation of $\left[6-{ }^{3} \mathrm{H}\right]$ glucose infusion rates.

Serum insulin was measured by radioimmunoassay with insulin antibody precipitate [23]. Commercially available reagent kits were used for the measurement of serum NEFA (Wako Chemicals, Neuss, Germany), $\beta$-hydroxybutyrate (Randox Laboratories, Crumlin, UK) and serum glycerol (Randox Laboratories).

Calculations. The non-steady-state equations of Steele [24], as modified by De Bodo et al. [25] were used to determine rates of glucose appearance $\left(R_{\mathrm{a}}\right)$ and disappearance $\left(\mathrm{R}_{\mathrm{d}}\right)$ during the periods -30 to $0 \mathrm{~min}$ and 90 to $120 \mathrm{~min}$, assuming a pool fraction value of 0.65 and an extracellular volume of $190 \mathrm{ml} \cdot \mathrm{kg}^{-1}$. Infusion rates of $\left[6{ }^{3} \mathrm{H}\right] \mathrm{glucose}$ were calculated as the sum of the tracer infused continuously and the tracer in the labelled exogenous glucose infusion. Rates of endogenous (hepatic) glucose production (EGP) were then calculated by subtraction of the exogenous glucose infusion rates required to maintain euglycaemia from the isotopically determined rates of glucose appearance.

\section{Statistical analysis}

The power of the study, calculated from previous clamp data $[16,26]$, was adequate to have a $90 \%$ chance of detecting a $10 \%$ change in insulin action at the $5 \%$ level of significance. The blood pressure and biochemical values at the end of each period of placebo or active treatment were used for statistical analysis according to that recommended by Hills and Armitage [27]. This method enables the comparison of low and conventional dose bendrofluazide to be adjusted for any period effects and also supplies a test for treatment-period interaction. The comparison of doses is derived from the differences in responses between the two periods. Significance is assessed with a $t$-statistic. No carryover effect was detected for any of the variables measured and there was therefore no necessity to analyse any variables as a parallel study. The values given in the text and figures are means \pm SEM. The level of significance was chosen at the $5 \%$ level. The significance level was reduced to the $1 \%$ level to correct for multiple testing with baseline.
Table 1. Effect of treatment with low- $(1.25 \mathrm{mg})$ and conventional- $(5.0 \mathrm{mg})$ dose bendrofluazide on systolic and diastolic blood pressure in NIDDM

\begin{tabular}{llrrrr}
\hline $\begin{array}{l}\text { Blood } \\
\text { pressure } \\
\text { (mm Hg) }\end{array}$ & $\begin{array}{l}\text { Dose } \\
(\mathrm{mg})\end{array}$ & \multicolumn{5}{l}{ Weeks of treatment } \\
\cline { 3 - 6 } & & \multicolumn{1}{l}{4} & \multicolumn{1}{l}{8} & \multicolumn{1}{l}{12} \\
\hline Systolic & 1.25 & $172 \pm 6$ & $160 \pm 5^{\mathrm{a}}$ & $156 \pm 6^{\mathrm{a}}$ & $151 \pm 6^{\mathrm{a}}$ \\
& 5.00 & $172 \pm 5$ & $156 \pm 5^{\mathrm{a}}$ & $152 \pm 6^{\mathrm{a}}$ & $149 \pm 6^{\mathrm{c}}$ \\
Diastolic & 1.25 & $97 \pm 3$ & $91 \pm 3^{\mathrm{b}}$ & $89 \pm 2^{\mathrm{c}}$ & $89 \pm 3^{\mathrm{b}}$ \\
& 5.00 & $99 \pm 4$ & $92 \pm 2^{\mathrm{b}}$ & $89 \pm 3^{\mathrm{c}}$ & $88 \pm 3^{\mathrm{b}}$ \\
\hline
\end{tabular}

Data are given as mean \pm SEM

${ }^{\mathrm{a}} p<0.005$ vs baseline; ${ }^{\mathrm{b}} p<0.001$ vs baseline; ${ }^{\mathrm{c}} p<0.0001$ vs baseline

\section{Results}

Eighteen patients were enlisted for the study and 14 of these fulfilled the entry criteria. Of the four patients who were withdrawn before the first active treatment period, three had a diastolic blood pressure less than $95 \mathrm{~mm} \mathrm{Hg}$ at the end of the placebo run-in phase and one withdrew during the placebo phase. One patient withdrew during the first active treatment period. Thirteen patients $(7$ males $/ 6 \mathrm{fe}$ males, age $61 \pm 1$ years, body mass index $26.7 \pm 0.9 \mathrm{~kg} \cdot \mathrm{m}^{-2}$ ) completed the full protocol. At the end of the placebo run-in these patients had a mean blood pressure of $176 \pm 5 / 99 \pm 2 \mathrm{mmHg}$. Seven patients were on dietary therapy alone, five patients were on sulphonylurea derivatives and one patient was taking metformin.

Patient compliance was good with over $95 \%$ of tablets being consumed by all participants. The effects of each dose of bendrofluazide on systolic and diastolic pressures are shown in Table 1 . The $1.25 \mathrm{mg}$ and $5.0 \mathrm{mg}$ doses of bendrofluazide produced significant decreases in systolic and diastolic blood pressure after 12 weeks' therapy. There were no statistically significant differences between the two doses after 12 weeks. After 12 weeks there was no change in body weight from baseline with either dose of bendrofluazide $(73.0 \pm 2.7$ to $72.7 \pm 2.7 \mathrm{~kg}$ with $5.0 \mathrm{mg}, 72.2 \pm 3.1$ to $71.9 \pm 3.3 \mathrm{~kg}$ with $1.25 \mathrm{mg}$; $p=$ NS for both).

The effects of treatment on various biochemical variables are shown in Table 2. Bendrofluazide $5.0 \mathrm{mg}$ produced a greater reduction in serum potassium concentration $(0.6 \pm 0.1 \mathrm{mmol} / \mathrm{l})$ than bendrofluazide $1.25 \mathrm{mg}(0.2 \pm 0.1 \mathrm{mmol} / \mathrm{l})$. In no case $\mathrm{did}$ the serum potassium fall below $3.3 \mathrm{mmol} / \mathrm{l}$. For serum urate, bendrofluazide $1.25 \mathrm{mg}$ had significantly less effect than bendrofluazide $5.0 \mathrm{mg}$. Bendrofluazide $5.0 \mathrm{mg}$ produced a greater effect on fasting blood glucose and $\mathrm{HbA}_{1 \mathrm{c}}$ levels than bendrofluazide $1.25 \mathrm{mg}$. Treatment with bendrofluazide $5.0 \mathrm{mg}$ produced significant increases in fasting glucose $(2.0 \pm 0.5 \mathrm{mmol} / \mathrm{l})$ and $\mathrm{HbA}_{1 \mathrm{c}}$ levels $(1.0 \pm 0.2 \%)$ 
Table 2. Effect of treatment with low- $(1.25 \mathrm{mg})$ and conventional- $(5.0 \mathrm{mg})$ dose bendrofluazide on electrolytes, urate, glucose, $\mathrm{HbA}_{1 \mathrm{c}}$ and lipids

\begin{tabular}{|c|c|c|c|c|}
\hline & \multicolumn{4}{|l|}{ Drug dose } \\
\hline & \multicolumn{2}{|l|}{$1.25 \mathrm{mg}$} & \multicolumn{2}{|l|}{$5.00 \mathrm{mg}$} \\
\hline & 0 & 12 & $\overline{0}$ & 12 Weeks \\
\hline Sodium $(\mathrm{mmol} / \mathrm{l})$ & $141 \pm 1$ & $140 \pm 1$ & $140 \pm 1$ & $139 \pm 1$ \\
\hline Potassium $(\mathrm{mmol} / \mathrm{l})$ & $4.2 \pm 0.1$ & $4.0 \pm 0.1$ & $4.3 \pm 0.1$ & $3.8 \pm 0.1^{\mathrm{c}, \mathrm{e}}$ \\
\hline Creatinine $(\mu \mathrm{mol} / \mathrm{l})$ & $85 \pm 6$ & $86 \pm 4$ & $87 \pm 3$ & $91 \pm 4$ \\
\hline Urate $(\mathrm{mmol} / \mathrm{l})$ & $0.34 \pm 0.01$ & $0.34 \pm 0.01$ & $0.34 \pm 0.01$ & $0.37 \pm 0.01^{\mathrm{a}, \mathrm{d}}$ \\
\hline Fasting glucose $(\mathrm{mmol} / \mathrm{l})$ & $7.0 \pm 0.5$ & $7.6 \pm 0.6$ & $7.0 \pm 0.6$ & $9.0 \pm 0.8^{\mathrm{b}, \mathrm{d}}$ \\
\hline $\mathrm{HbA}_{1 \mathrm{c}}(\%)$ & $5.2 \pm 0.3$ & $5.2 \pm 0.4$ & $4.8 \pm 0.4$ & $5.9 \pm 0.4^{c, d}$ \\
\hline Cholesterol $(\mathrm{mmol} / \mathrm{l})$ & $5.67 \pm 0.36$ & $5.76 \pm 0.36$ & $5.88 \pm 0.32$ & $5.84 \pm 0.34$ \\
\hline LDL-cholesterol (mmol/l) & $3.75 \pm 0.30$ & $3.59 \pm 0.33$ & $3.89 \pm 0.28$ & $3.76 \pm 0.30$ \\
\hline HDL-cholesterol (mmol/I) & $1.34 \pm 0.07$ & $1.28 \pm 0.06$ & $1.31 \pm 0.04$ & $1.25 \pm 0.07$ \\
\hline Triglycerides $(\mathrm{mmol} / \mathrm{l})$ & $1.50 \pm 0.15$ & $1.80 \pm 0.22$ & $1.69 \pm 0.19$ & $2.01 \pm 0.22$ \\
\hline
\end{tabular}

Data are given as mean \pm SEM

${ }^{\mathrm{a}} p<0.01$ vs baseline; ${ }^{\mathrm{b}} p<0.005$ vs baseline; ${ }^{\mathrm{c}} p<0.001 \mathrm{vs}$ baseline; ${ }^{\mathrm{d}} p<0.051 .25 \mathrm{vs} 5.0 \mathrm{mg}$; ${ }^{\mathrm{e}} p<0.011 .25 \mathrm{vs} 5.0 \mathrm{mg}$

Table 3. Euglycaemic glucose clamps at baseline and following 12 weeks' treatment with low- $(1.25 \mathrm{mg})$ and conventional(5.0 mg) dose bendrofluazide

\begin{tabular}{lccc}
\hline & Basal & $1.25 \mathrm{mg}$ & $5.0 \mathrm{mg}$ \\
\hline Fasting glucose $(\mathrm{mmol} / \mathrm{l})$ & $7.5 \pm 0.5$ & $8.2 \pm 0.6^{\mathrm{a}, \mathrm{c}}$ & $8.8 \pm 0.7^{\mathrm{b}, \mathrm{c}}$ \\
Mean clamp glucose $(\mathrm{mmol} / \mathrm{l})$ & $7.3 \pm 0.4$ & $7.1 \pm 0.4$ & $7.2 \pm 0.4$ \\
Fasting serum insulin $(\mathrm{mU} / \mathrm{l})$ & $11.7 \pm 2.3$ & $13.3 \pm 2.7$ & $15.3 \pm 2.9^{\mathrm{b}}$ \\
Steady-state clamp insulin $(\mathrm{mU} / \mathrm{l})$ & $156 \pm 12$ & $153 \pm 12$ & $160 \pm 16$ \\
Exogenous glucose infusion rate & $27.3 \pm 3.5$ & $26.8 \pm 3.6^{\mathrm{c}}$ & $23.8 \pm 2.9^{\mathrm{a}, \mathrm{c}}$ \\
$\left(90-120 \mathrm{~min} ; \mu \mathrm{mol} \cdot \mathrm{kg}^{-1} \cdot \mathrm{min}^{-1}\right)$ & & & \\
Postabsorptive EGP $\left(\mu \mathrm{mol} \cdot \mathrm{kg}^{-1} \cdot \mathrm{min}^{-1}\right)$ & $10.6 \pm 0.4$ & $10.2 \pm 0.3^{\mathrm{c}}$ & $11.7 \pm 0.5^{\mathrm{a}, \mathrm{c}}$ \\
EGP during clamp & $2.2 \pm 4$ & $2.0 \pm 0.4^{\mathrm{c}}$ & $4.0 \pm 0.7^{\mathrm{a}, \mathrm{c}}$ \\
$\left(90-120 \mathrm{~min} ; \mu \mathrm{mol} \cdot \mathrm{kg}^{-1} \cdot \mathrm{min}^{-1}\right)$ & & & \\
$\mathrm{R}_{\mathrm{a}}$ & $29.4 \pm 3.6$ & $28.8 \pm 3.0$ & $27.8 \pm 3.1$ \\
$\left(90-120 \mathrm{~min} ; \mu \mathrm{mol} \cdot \mathrm{kg}^{-1} \cdot \mathrm{min}^{-1}\right)$ & & & \\
$\mathrm{R}_{\mathrm{d}}$ & $29.9 \pm 3.4$ & $28.6 \pm 3.3$ & $28.2 \pm 2.9$ \\
$\left(90-120 \mathrm{~min} ; \mu \mathrm{mol} \cdot \mathrm{kg}^{-1} \cdot \mathrm{min}^{-1}\right)$ & & & \\
\hline
\end{tabular}

Data are given as mean \pm SEM

${ }^{\mathrm{a}} p<0.05$ vs baseline; ${ }^{\mathrm{b}} p<0.005$ vs baseline; ${ }^{\mathrm{c}} p<0.051 .25 \mathrm{vs} 5.0 \mathrm{mg}$

after 12 weeks. Unfavourable changes in fasting glucose and $\mathrm{HbA}_{1 \mathrm{c}}$ were already present after 4 weeks of treatment with bendrofluazide $5.0 \mathrm{mg}$ (data not shown). Low-dose bendrofluazide produced no significant change in either index of glycaemic control throughout the treatment period (Table 2). There were no statistically significant changes in total cholesterol, LDL-cholesterol, HDL-cholesterol or total triglycerides with either treatment, nor were there any significant differences between treatments (Table 2).

Results from the euglycaemic glucose clamp studies are summarised in Table 3. Fasting arterialised venous plasma glucose levels were increased following treatment with both doses of bendrofluazide but the increase was significantly greater with the $5.0 \mathrm{mg}$ dose. Fasting serum insulin was significantly increased after 12 weeks' treatment with $5.0 \mathrm{mg}$ bend- rofluazide but not with $1.25 \mathrm{mg}$. There was no significant difference between doses in terms of effect on fasting insulin. Plasma glucose levels during the clamp studies were similar with mean coefficients of variation less than $3.6 \%$. The insulin infusion of $2 \mathrm{mU} \cdot \mathrm{kg}^{-1} \cdot \mathrm{min}^{-1}$ led to comparable levels of steady-state plasma insulin. Exogenous glucose infusion rates required to maintain euglycaemia during the last 30 min of the glucose clamp (an index of peripheral insulin sensitivity) were significantly lower following treatment with $5.0 \mathrm{mg}$ bendrofluazide compared with $1.25 \mathrm{mg}$ and significantly reduced compared with baseline (Table 3 ). Low-dose bendrofluazide produced no change in insulin-mediated glucose disposal compared to baseline.

Postabsorptive endogenous glucose production EGP, an index of hepatic insulin sensitivity, was higher on treatment with $5.0 \mathrm{mg}$ bendrofluazide com- 


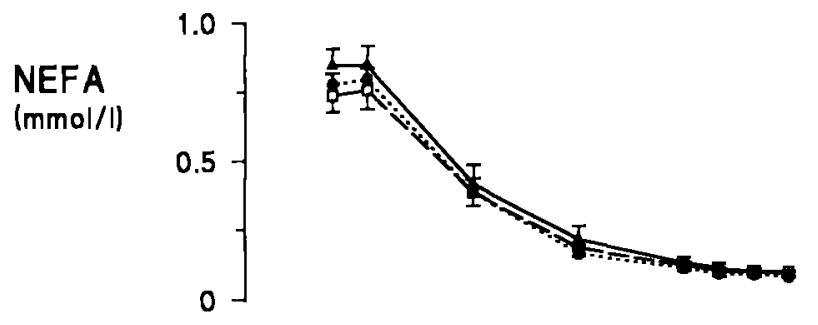

seen after low-dose bendrofluazide $(21 / 8 \mathrm{~mm} \mathrm{Hg})$ was comparable to that reported in a large parallel group study in non-diabetic hypertensive subjects $(13 / 10 \mathrm{~mm} \mathrm{Hg})$ [10]. Furthermore, we have shown low-dose bendrofluazide to have no detrimental effects on peripheral or hepatic insulin action. In contrast, treatment with conventional-dose bendrofluazide worsened peripheral and hepatic insulin resistance and produced a deterioration in glycaemic control.

Treatment with conventional-dose bendrofluazide $(5.0 \mathrm{mg})$ produced a $13 \%$ reduction in peripheral insulin sensitivity compared to baseline. This impairment in peripheral insulin action is of similar magnitude to that seen with comparable doses of hydrochlorothiazide in non-diabetic hypertensive subjects [15]. In contrast, treatment with low-dose bendrofluazide $(1.25 \mathrm{mg})$ produced no change in peripheral insulin action compared to baseline and clear differences between doses were observed. Low-dose hydrochlorothiazide has also been shown to have negligible effects on insulin-mediated glucose disposal in NIDDM subjects [14]. The current study clearly shows that the use of a lower than conventional dose of bendrofluazide does not worsen the peripheral insulin resistance of hypertensive NIDDM subjects.

As well as exhibiting significant peripheral insulin

Fig.1. Change in serum NEFA, $\beta$-hydroxybutyrate $(\beta-\mathrm{OH})$ and glycerol during glucose clamp studies. - - Basal; -.- $\square-\cdots 1.25 \mathrm{mg} ; \cdots \cdots 5.0 \mathrm{mg}$

pared to $1.25 \mathrm{mg}$ and suppressed to a lesser extent following insulin (Table 3). Postabsorptive EGP increased significantly following treatment with $5.0 \mathrm{mg}$ as compared to baseline whereas $1.25 \mathrm{mg}$ had no effect compared to baseline (Table 3).

Postabsorptive levels of serum NEFA, $\beta$-hydroxybutyrate and glycerol were unchanged following treatment with either dose. During hyperinsulinaemia rapid suppression to a similar extent was seen with both doses (Fig. 1).

\section{Discussion}

Although diabetes is associated with a considerably increased cardiovascular risk the additional presence of hypertension markedly increases morbidity and mortality [1]. For this reason increasing attention is being paid to the management of raised blood pressure in diabetic patients. The choice of antihypertensive therapy presents special problems in diabetic patients and there is no general agreement about which agent is most suitable.

In this study of hypertensive NIDDM subjects reduction in blood pressure was similar after treatment with both low - and conventional - dose bendrofluazide. The magnitude of the antihypertensive effect resistance, NIDDM subjects demonstrate hepatic insulin resistance with a raised postabsorptive hepatic glucose production and impaired suppression of glucose output during hyperinsulinaemia [28]. Hepatic glucose production is closely correlated with the degree of fasting hyperglycaemia. We have demonstrated a small but significant increase in basal EGP $(10 \%)$ with the use of conventional dose bendrofluazide. As basal insulin levels were also increased and suppression of EGP impaired, this represents induction of a degree of hepatic insulin resistance. Insulininduced suppression of lipolysis (as reflected in the suppression of NEFA during hyperinsulinaemia) was not impaired following treatment with $5 \mathrm{mg}$ bendrofluazide indicating that hepatic insulin resistance does not extend to effects on lipid metabolism. We have noted a similar impairment in hepatic insulin action with the use of conventional doses of cyclopenthiazide [26] and bendrofluazide [16] in non-diabetic hypertensive subjects. This study also shows that with the use of low doses of bendrofluazide the deterioration in hepatic insulin action seen with more conventional doses is avoided.

We did observe a small increase in fasting glucose with the use of low-dose bendrofluazide. This increase was never statistically significant in repeated venous glucose measurements throughout the treatment period but did reach significance in a single arterialised venous sample on the morning of the glucose clamp study. Low-dose bendrofluazide produced no change in $\mathrm{HbA}_{1 \mathrm{c}}$ levels after 12 weeks. 
Longer-term studies are necessary to ensure that hyperglycaemia does not occur with prolonged use of low-dose bendrofluazide.

A differential effect between doses was also evident for serum potassium and urate. The dose-response nature of thiazide effects on serum potassium and urate concentrations has been described previously [10-12]. Numerous studies have demonstrated that thiazide diuretics adversely effect lipids and lipoprotein profiles, at least in the short term [29, 30]. However, this was found when utilising relatively high doses of thiazides. Neither of the doses used in this study had any effect on the lipids measured.

In conclusion, we have demonstrated the effectiveness of $1.25 \mathrm{mg}$ bendrofluazide daily in the treatment of mildly hypertensive NIDDM patients. Compared to a more conventional dose, low-dose bendrofluazide produced no adverse metabolic effects and in particular no deleterious effects on either peripheral or hepatic insulin action. In contrast, the use of bendrofluazide at a more conventional dose of $5.0 \mathrm{mg}$ daily produced hypokalaemia, hyperuricaemia, a deterioration in glycaemic control and impairments in both peripheral and hepatic insulin action. Worsening peripheral and hepatic insulin action are the mechanisms by which conventional dose thiazide diuretics produce their well-recognized effects on glucose homeostasis. However, the use of $1.25 \mathrm{mg}$ bendrofluazide can successfully decrease blood pressure with minimal upset to the metabolic profile over a 12-week period.

Acknowledgements. We are grateful to Dr. C.Patterson, Department of Community Medicine and Medical Statistics, The Queen's University of Belfast for statistical advice. We also thank Mr. N. Bell for performing the metabolite assays. We acknowledge the Pharmacy Department, Royal Victoria Hospital for help with randomisation and drug dispensing. During the course of these studies, Dr. R. Harper was a Royal Victoria Hospital Research Fellow. This work was supported by a grant from the Northern Ireland Chest Heart and Stroke Association.

\section{References}

1. Fuller JH (1985) Epidemiology of hypertension associated with diabetes mellitus. Hypertension 7 [Suppl 2]: 3-7

2. The Working Group on Hypertension in Diabetes (1987) Statement on hypertension in diabetes mellitus. Arch Intern Med 147: 830-842

3. Hollander W, Wilkins RW (1957) Chlorothiazide: a new type of drug for the treatment of arterial hypertension. Boston Medical Quarterly 8: 68-75

4. Medical Research Council Working Party (1985) MRC trial of treatment of mild hypertension: principal results. BMJ 291: 97-104

5. Management Committee of the Australian Therapeutic Trial in Mild Hypertension (1980) Report. Lancet i: 12611267

6. MacMahon SW, Cutler JA, Furberg CD, Payne GH (1986) The effects of drug treatment for hypertension on morbid- ity and mortality from cardiovascular disease: a review of randomised controlled trials. Prog Cardiovasc Dis 29 [Suppl 1]: 99-118

7. Kaplan NM (1986) Problems with the use of diuretics in the treatment of hypertension. Am J Nephrol 6: 1-5

8. Knochel JP (1984) Diuretic-induced hypokalaemia. Am J Med 77: 18-27

9. Weinberger MH (1985) Antihypertensive therapy and lipids. Evidence, mechanisms, and implications. Arch Intern Med 145: 1103-1105

10. Carlsen JE, Kober L, Torp-Pedersen L, Johansen P (1990) Relation between dose of bendrofluazide, antihypertensive effect and adverse biochemical effects. BMJ 300: 975978

11. McVeigh G, Galloway D, Johnston D (1988) The case for low dose diuretics in hypertension; comparison of low and conventional doses of cyclopenthiazide. BMJ 297: 95-98

12. Burris JF, Weir MR, Oparil S, Weber M, Cady WJ, Stewart WH (1990) An assessment of diltiazem and hydrochlorothiazide in hypertension. Application of factorial trial design to a multicenter clinical trial of combination therapy. JAMA 263: 1507-1512

13. Passmore AP, Whitehead EM, Crawford V, McVeigh GE, Johnston GD (1991) The antihypertensive and metabolic effects of low and conventional dose cyclopenthiazide in type II diabetics with hypertension. Quarterly Journal of Medicine 81: 919-928

14. Prince MJ, Stuart CA, Padia M, Bandi Z, Holland OB (1988) Metabolic effects of hydrochlorothiazide and enalapril during treatment of the hypertensive diabetic patient. Arch Intern Med 148: 2363-2368

15. Pollare T, Lithell H, Selinus I, Berne C (1989) A comparison of the effects of hydrochlorothiazide and captopril on glucose and lipid metabolism in patients with hypertension. N Engl J Med 321: 868-873

16. Harper R, Ennis C, Atkinson AB, Johnston GD, Bell PM (1994) Effect of low and conventional dose bendrofluazide on insulin action in essential hypertension. BMJ 309: 226230

17. Firth RG, Bell PM, Rizza RA (1986) Effect of tolazamide and exogenous insulin on insulin action in patients with non-insulin-dependent diabetes mellitus. $\mathrm{N}$ Engl J Med 314: 1280-1286

18. DeFronzo RA, Tobin JD, Andres R (1979) Glucose clamp technique: a method for quantifying insulin secretion and resistance. Am J Physiol 237: E214-E223

19. Neely RDG, Rooney DP, Atkinson AB et al. (1990) Underestimation of glucose turnover determined using [6$\left.{ }^{3} \mathrm{H}\right]$ glucose tracer in non-steady state: the role of a tritiated tracer impurity. Diabetologia 33: 681-687

20. Hother-Nielsen O, Beck-Nielsen H (1990) On the determination of basal glucose production rate in patients with type 2 (non-insulin-dependent) diabetes mellitus using primed-continuous $3-{ }^{3} \mathrm{H}$-glucose infusion. Diabetologia 33: 603-610

21. Neely RDG, Rooney DP, Bell PM et al. (1992) Influence of growth hormone on glucose-glucose 6-phosphate cycle and insulin action in normal humans. Am J Physiol 263: E980E987

22. Somogyi M (1945) Determination of blood sugar. J Biol Chem 160: 69-73

23. Hales CN, Randle PJ (1963) Immunoassay of insulin with insulin antibody precipitate. Biochem J 88: 137-146

24. Steele R, Wall JS, De Bodo RC, Altszuler N (1956) Measurement of size and turnover rate of body glucose pool by the isotope dilution method. Am J Physiol 187: $15-25$ 
25. De Bodo RC, Steele R, Altszuler N, Dunn A, Bishop JS (1963) On the hormonal regulation of carbohydrate metabolism; studies with C14 glucose. Rec Prog Horm Res 19: $445-488$

26. Rooney DP, Neely RDG, Ennis CN et al. (1992) Insulin action and hepatic glucose cycling in essential hypertension. Metabolism 41: 317-324

27. Hills M, Armitage $P(1979)$ The two-period cross-over clinical trial. Br J Clin Pharmacol 8: 7-20
28. DeFronzo RA (1992) Pathogenesis of type 2 (non-insulindependent) diabetes mellitus: a balanced overview. Diabetologia 35: 389-397

29. Grimm RH Jr, Leon AS, Hunninghake DB, Lenz K, Hannan P, Blackburn H (1981) Effects of thiazide diuretics on plasma lipids and lipoproteins in mildly hypertensive patients: a double blind controlled trial. Ann Intern Med 94: $7-11$

30. Ames RP, Hill P (1976) Elevation of serum lipids during diuretic therapy of hypertension. Am J Med 61: 748-757 